\title{
Pleural Effusion in a Patient With Allergic Bronchopulmonary Aspergillosis
}

\author{
Karan Madan MD DM, Amanjit Bal MD DNB, and Ritesh Agarwal MD DM
}

\begin{abstract}
The involvement of pleura in patients with allergic bronchopulmonary aspergillosis (ABPA) is uncommon. In most reported cases the involvement of the pleura is presumed to be due to ABPA per se, due to the observed response to corticosteroids. We report a case of histopathologically proven tubercular pleural effusion in a patient with ABPA at the time of initial diagnosis. This case highlights the importance of intensive evaluation of an exudative pleural effusion in settings where pleural effusion due to the primary underlying disease is uncommon or rare. Key words: bronchopulmonary aspergillosis; pleural effusion; ABPA; Aspergillus fumigatus. [Respir Care 2012;57(9):15091513. (C) 2012 Daedalus Enterprises]
\end{abstract}

\section{Introduction}

The pathogenic mechanism underlying allergic bronchopulmonary aspergillosis (ABPA) is hypersensitivity to the fungus Aspergillus fumigatus. ${ }^{1}$ The important clinical manifestations include chronic asthma, recurrent pulmonary infiltrates, and bronchiectasis. Radiologically, ABPA is classified as seropositive ABPA (ABPA-S), ABPA with central bronchiectasis and ABPA with central bronchiectasis and with high attenuation mucus, depending on the absence or presence of bronchiectasis and high attenuation mucus. $^{2}$

Although numerous radiological findings have been described in ABPA, pleural involvement is an extremely uncommon manifestation. ${ }^{3}$ Moreover, concomitant tuberculous pleural effusion in a patient with active ABPA has never been previously reported. We report a case in which the diagnosis of tubercular pleural effusion was established

\footnotetext{
Drs Madan and Agarwal are affiliated with the Department of Pulmonary Medicine; and Dr Bal is affiliated with the Department of Histopathology, Postgraduate Institute of Medical Education and Research, Chandigarh, India.

The authors have disclosed no conflicts of interest.

Correspondence: Ritesh Agarwal MD DM, Department of Pulmonary Medicine, Postgraduate Institute of Medical Education and Research, Sector 12, Chandigarh 160012, India. E-mail: riteshpgi@gmail.com; agarwal.ritesh@pgimer.edu.in.
}

DOI: $10.4187 /$ respcare. 01670 at the time of initial diagnosis of ABPA. We also performed a systematic review of literature of all the cases of pleural effusions complicating the course of ABPA.

\section{Case Report}

A 22-year-old female presented to the chest clinic with history of fever, worsening breathlessness, dry cough, and right side pleuritic chest pain of 4 weeks duration. There was no history of hemoptysis. She was diagnosed as having asthma of 4 years duration and was treated with oral theophylline, but had never received any inhaled medications. Her asthma control was poor, but there was no history of asthma exacerbations requiring hospitalization. The patient had been treated for chronic fungal sinusitis 4 years earlier, and had undergone functional endoscopic sinus surgery. She had also received oral itraconazole and nasal steroids for one year, after which she had been asymptomatic for the nasal symptoms. There was no previous history of tuberculosis (TB) or close contact with any case of TB.

On examination the patient was febrile $\left(38.3^{\circ} \mathrm{C}\right)$, heart rate was 100 beats/min, blood pressure was $120 / 76 \mathrm{~mm} \mathrm{Hg}$, and respiratory rate was 24 breaths/min. General physical examination was unremarkable. On auscultation, the breath sounds were diminished in intensity over the right infrascapular area, with diffuse wheeze in the rest of the lung fields. A chest radiograph confirmed the presence of a right sided pleural effusion. Tuberculin skin test performed with 5 tuberculin units was negative. Sputum smear for acid-fast bacilli was negative on 2 occasions. In view of a history of asthma, screening tests for ABPA were per- 


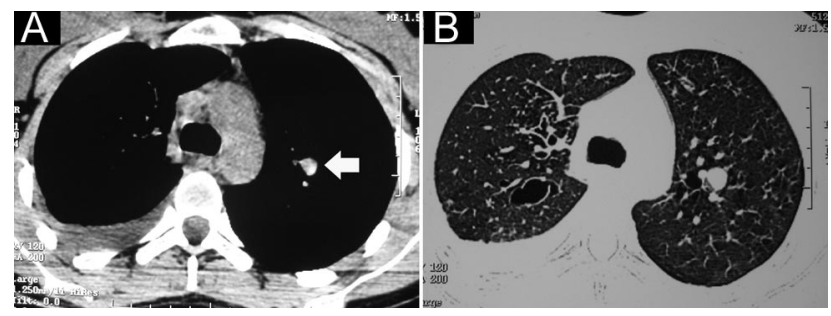

Fig. 1. A: High-resolution computed tomography of the chest shows right sided pleural effusion and high-attenuation mucus in one of the bronchiectatic cavities (arrow). B: The corresponding lung window depicting the areas of central bronchiectasis.

formed per the chest clinic's protocol. She demonstrated immediate cutaneous hypersensitivity to A. fumigatus antigen; serum immunoglobulin-E levels, both total (7,800 IU/ $\mathrm{mL}$, normal 0-100) and A. fumigatus specific (2.89 kilounits of antibody per liter, normal $<0.35)$ were elevated, and the total eosinophil count was 780 cells/ $\mu$ L. Serum precipitins to A. fumigatus were positive. High-resolution computed tomography of the thorax demonstrated a right pleural effusion with high-attenuation mucus plug. Lung window sections showed centrilobular nodules with tree in bud appearance in both the lung fields. In addition, bilateral central bronchiectasis was seen (Fig. 1). A possibility of ABPA with central bronchiectasis with pleural involvement secondary to ABPA was considered.

Pleural fluid analysis revealed a cell count of 400 cells $/ \mu \mathrm{L}$ with lymphocyte predominance, protein levels of $5.8 \mathrm{~g} / \mathrm{dL}$, and glucose of $80 \mathrm{mg} / \mathrm{dL}$. Pleural fluid adenosine deaminase levels were 24 units/L. Bacterial cultures were sterile, and stain for an acid-fast bacillus was negative. Cytological examination was negative for malignant cells. Subsequently, a medical thoracoscopy was performed using the rigid thoracoscope (operating laparoscope $10 \mathrm{~mm}$, with $5 \mathrm{~mm}$ working channel, distortion free with right angled eye piece, Richard Wolf Medical Instruments, Vernon Hills, Illinois). There were multiple thin adhesions between the parietal and visceral pleural surfaces, along with a diffuse fine pleural nodularity (Fig. 2). Adhesiolysis was performed at the time of thoracoscopy, and a pleural biopsy was obtained (rigid biopsy forceps, spiked with both jaws opening, Richard Wolf Medical Instruments, Vernon Hills, Illinois). Post procedure, an intercostal drain was inserted on the right side, which was removed 2 days later. Histopathological examination of the sections obtained from the parietal pleura demonstrated multiple epithelioid cell granulomas, with multinucleate giant cells; there was no eosinophilic inflammation, and the stain for acid-fast bacilli was negative. A final diagnosis of tuberculous pleural effusion with ABPA was made.

Antitubercular treatment with isoniazid, rifampicin, ethambutol, and pyrazinamide, was initiated. High-dose inhaled corticosteroids and long-acting $\beta_{2}$ agonist (for-

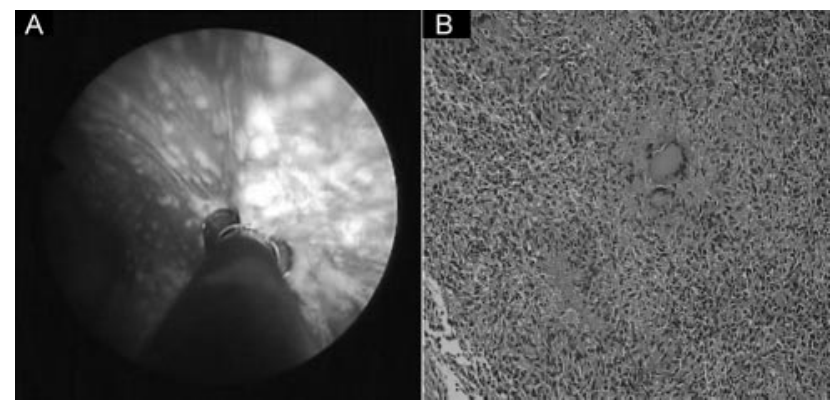

Fig. 2. A: Thoracoscopic image showing extensive fine nodularity over the parietal pleural surface, and pleural biopsy being taken. B: Histopathology image of the pleural biopsy, demonstrating numerous epithelioid cell granulomas.

moterol/budesonide combination $6 / 200 \mu \mathrm{g}, 2$ puffs twice a day and as required) was initiated for asthma control. At 2 months follow-up, the asthma was well controlled, and effusion resolved completely. Culture of pleural biopsy specimen grew Mycobacterium tuberculosis. The total immunoglobulin-E levels increased to $12,600 \mathrm{IU} / \mathrm{mL}$, hence the patient was also started on itraconazole $200 \mathrm{mg}$ twice a day.

\section{Discussion}

Pleural involvement in ABPA is uncommon, and involvement of the pleura has been described in the form of parenchymal lesions extending up to the pleural surface or pleural thickening on radiology in up to $43-82 \%$ patients with ABPA, in various small series. ${ }^{4,5}$ The other reported pleural manifestation is secondary spontaneous pneumothorax. ${ }^{6-11}$ Pleural effusion is a rarely reported clinical presentation of ABPA. A systematic search of the PubMed database, using the free text terms "ABPA" and "allergic bronchopulmonary aspergillosis," yielded 6 citations that have described the occurrence of pleural effusion in ABPA. ${ }^{5,12-16}$

Since the description of the first case of pleural effusion in a patient with ABPA in 1981, only 7 cases have been reported to date (Table). All the cases except one had unilateral effusion. ${ }^{14}$ Diagnostic thoracentesis was performed in all but one case. In 4 out of the 6 cases in which a diagnostic thoracentesis was performed, the cell population comprised predominantly lymphocytes or neutrophils. ${ }^{5,12-14}$ The other 2 cases manifested with eosinophilic pleural effusion, and of these one developed effusion during a relapse of ABPA. ${ }^{15,16}$ The pleural fluid in one of the cases, along with eosinophilia, had empyematous characteristics, with a low pH, low glucose, and high eosinophil count. ${ }^{16}$ Such inflammatory features were proposed to be likely related to high metabolic activity of the eosinophils. Recurrence/appearance of pleural effusion after treatment with corticosteroids has been reported in 2 cases. The 
Pleural Effusion in a Patient With Allergic Bronchopulmonary Aspergillosis

Table. Clinical Details and Outcome of All Cases of Pleural Effusion Complicating ABPA Reported in the Literature To Date

\begin{tabular}{|c|c|c|c|c|c|c|c|c|c|}
\hline $\begin{array}{l}\text { First } \\
\text { Author }\end{array}$ & Year & $\begin{array}{c}\text { Age, } \\
\mathrm{y}\end{array}$ & Sex & $\begin{array}{l}\text { Side of } \\
\text { Effusion }\end{array}$ & $\begin{array}{l}\text { Pleural Fluid } \\
\text { Nature }\end{array}$ & Work-up for ABPA & $\begin{array}{c}\text { Associated } \\
\text { Lung Collapse } \\
\text { (segmental or } \\
\text { complete) }\end{array}$ & $\begin{array}{l}\text { Histopathology } \\
\text { of Pleura }\end{array}$ & Clinical Course \\
\hline Murphy ${ }^{12}$ & 1981 & 12 & Male & Right & $\begin{array}{l}\text { NA } \\
\text { Lymphocytes }\end{array}$ & $\begin{array}{l}\text { Type } 1 \text { AST: positive } \\
\text { IgE: ND } \\
\text { Aspergillus fumigatus } \\
\text { precipitins: positive } \\
\text { A. fumigatus IgE: ND } \\
\text { TEC: } 1,600 \text { cells/ } \mu \mathrm{L}\end{array}$ & Yes & $\begin{array}{l}\text { Chronic } \\
\quad \text { inflammation }\end{array}$ & $\begin{array}{l}\text { Spontaneous resolution; } \\
\text { no recurrence on } \\
\text { follow-up }\end{array}$ \\
\hline Murphy $^{12}$ & 1981 & 64 & Male & Left & $\begin{array}{l}\text { NA } \\
\text { Lymphocytes }\end{array}$ & $\begin{array}{l}\text { Type } 1 \text { AST: positive } \\
\text { IgE: ND } \\
\text { A. fumigatus } \\
\text { precipitins: positive } \\
\text { A. fumigatus } \text { IgE: ND } \\
\text { TEC: } 1,660 \text { cells/ } \mu \mathrm{L}\end{array}$ & Yes & $\begin{array}{l}\text { Chronic } \\
\quad \text { inflammation }\end{array}$ & $\begin{array}{l}\text { Responded to steroids; } \\
\text { recurrence on } \\
\text { follow-up, responded } \\
\text { to increase in } \\
\text { steroid dose }\end{array}$ \\
\hline Bhagat $^{13}$ & 1993 & 38 & Female & Left & $\begin{array}{l}\text { Exudate } \\
\text { Lymphocytes }\end{array}$ & $\begin{array}{l}\text { Type } 1 \text { AST: positive } \\
\text { IgE: } 280 \mathrm{IU} / \mathrm{mL} \\
\text { A. fumigatus } \\
\text { precipitins: positive } \\
\text { A. fumigatus IgE: ND } \\
\text { TEC: } 1,116 \text { cells/ } \mu \mathrm{L}\end{array}$ & Yes & Not done & $\begin{array}{l}\text { Responded to steroids; } \\
\text { no recurrence on } \\
\text { follow-up }\end{array}$ \\
\hline Panchal $^{5}$ & 1997 & 54 & Male & Left & NA & $\begin{array}{l}\text { Type } 1 \text { AST: positive } \\
\text { IgE: } 410 \text { IU/mL } \\
\text { A. fumigatus } \\
\text { precipitins: positive } \\
\text { A. fumigatus } \text { IgE: ND } \\
\text { TEC: } 2,624 \text { cells } / \mu \mathrm{L} \text { ) }\end{array}$ & Yes & Not done & NA \\
\hline O,Connor ${ }^{14}$ & 2001 & 27 & Male & Bilateral & $\begin{array}{l}\text { Exudate } \\
\text { Neutrophils }\end{array}$ & $\begin{array}{l}\text { Type } 1 \text { AST: positive } \\
\text { IgE: } 5,000 \mathrm{IU} / \mathrm{mL} \\
\text { A. fumigatus } \\
\text { precipitins: positive } \\
\text { A. fumigatus } \text { IgE: ND } \\
\text { TEC: } 1,610 \text { cells/ } \mu \mathrm{L}\end{array}$ & No & Not done & $\begin{array}{l}\text { Responded to steroids; } \\
\text { no recurrence on } \\
\text { follow-up }\end{array}$ \\
\hline Ogasawara $^{15}$ & 2003 & 61 & Male & Right & $\begin{array}{l}\text { Exudate } \\
\text { Eosinophilic }\end{array}$ & $\begin{array}{l}\text { Type } 1 \text { AST: positive } \\
\text { IgE: Elevated } \\
\text { A. fumigatus } \\
\text { precipitins: positive } \\
\text { A. fumigatus IgE: ND } \\
\text { central bronchiectasis }\end{array}$ & Yes & NA & $\begin{array}{l}\text { Effusion appeared during } \\
\text { relapse of ABPA; } \\
\text { responded to increase } \\
\text { in steroid dose and } \\
\text { addition of } \\
\text { itraconazole; } \\
\text { no recurrence } \\
\text { on follow-up }\end{array}$ \\
\hline Kirschner $^{16}$ & 2011 & 25 & Male & Left & $\begin{array}{l}\text { Exudate } \\
\text { Eosinophilic }\end{array}$ & $\begin{array}{l}\text { AST: ND } \\
\text { IgE: } 7,319 \mathrm{IU} / \mathrm{mL} \\
\text { A. fumigatus } \\
\text { precipitins: ND } \\
\text { A. fumigatus } \mathrm{IgE}: \\
65.5 \mathrm{kUA} / \mathrm{L} \\
\text { TEC: } 4,900 \text { cells } / \mu \mathrm{L}\end{array}$ & Yes & Not done & $\begin{array}{l}\text { Responded to steroids } \\
\text { and voriconazole; } \\
\text { no recurrence } \\
\text { on follow-up }\end{array}$ \\
\hline $\begin{array}{l}\text { ABPA }=\text { allergic } \\
\text { NA }=\text { not availab } \\
\text { AST }=\text { aspergillus } \\
\text { IgE }=\text { immunogio } \\
\text { TEC }=\text { total eosin } \\
\text { IU }=\text { international } \\
\mathrm{kUA}=\text { kilo-units }\end{array}$ & $\begin{array}{l}\text { bronchop } \\
\text { le } \\
\text { skin test } \\
\text { bulin-E } \\
\text { ophil cou } \\
\text { units } \\
\text { of antibo }\end{array}$ & $\begin{array}{l}\text { almonary } \\
\text { nt } \\
\text { dy per lit }\end{array}$ & aspergillosis & & & & & & \\
\hline
\end{tabular}


effusion responded in both cases with subsequent increase in corticosteroid dosage. ${ }^{12}$ History of recurrent pleurisy over 5 year duration prior to diagnosis was present in one of the reported cases. ${ }^{14}$

The mechanisms postulated for the development of pleural effusion in ABPA include an intensive inflammatory response, with release of cytokines and fungal translocation into the pleural space, leading to a local Th2-dependent inflammatory response or lung collapse, leading to "ex vacuo" pleural effusion. ${ }^{16}$ A case of ipsilateral pleural effusion has been reported in a patient with ABPA, allergic aspergillus sinusitis, and an operated aspergilloma. The effusion cleared, with re-expansion of the lobe after therapy with oral corticosteroids, and was proposed to be likely due to effects of the lung collapse. ${ }^{13}$ Another postulated mechanism is inflammatory pleural reaction, which occurs adjacent to inflamed lung tissue, leading to the development of an exudative effusion.

Although there is a broad differential diagnosis of eosinophilic pleural effusions, the description of only 2 such cases highlights the rarity of ABPA as a reported cause of eosinophilic pleural effusions. In a retrospective analysis of 2,205 pleural fluid samples from 1,868 patients over 12 year duration, 135 patients with eosinophilic pleural effusion (7.2\% of all patients with pleural effusion) were identified, out of whom none of the patients had ABPA. ${ }^{17}$

The occurrence of ABPA in patients with pulmonary TB has been rarely reported. ${ }^{18}$ ABPA has been reported to develop in patients with past history of pulmonary TB, ${ }^{19}$ and most are cases of ABPA misdiagnosed as pulmonary TB. ${ }^{20,21}$ Tuberculous pleural effusion complicating ABPA has never been previously reported, and the index patient represents the first such case. Approximately 5\% of patients with $M$. tuberculosis infection develop tubercular pleural effusion. Thoracoscopic pleural biopsy represents the most sensitive diagnostic test for tuberculous pleural effusions, with diagnostic yield approaching 100\%.22 Histopathologic examination may demonstrate granulomatous inflammation, caseation, or acid-fast bacilli. Tuberculous pleural effusion is primarily an immunologic response to tubercle bacilli; hence, acid-fast bacilli are often not observed. The natural history of tubercular pleural effusion is one of spontaneous resolution, even without treatment. However, the risk of developing severe forms of pulmonary TB many years later is increased in these patients. ${ }^{23}$

The index case adds to the literature on the involvement of pleura in patients with ABPA. Although a rare cause of pleural effusion, we initially considered ABPA as the etiology of the pleural effusion. However, due to the high TB prevalence and rarity of the occurrence of pleural effusion in ABPA, we aggressively pursued the diagnosis of this exudative pleural effusion by performing thoracoscopy. The importance of this case report lies in the fact that it suggests that, even in a diagnosed case of ABPA, pleural effusion due to ABPA per se is extremely rare. In fact, treatment with corticosteroids might have caused clearing of the tuberculous effusion, and the effusion would have been presumed to be secondary to ABPA. However, these patients are at risk of developing severe forms of pulmonary TB many years later, as pointed out earlier.

ABPA is a rare cause of pleural effusion, and attributing an exudative pleural effusion, even in the setting of ABPA, to ABPA per se may be associated with disastrous consequences, as the majority of these patients receive glucocorticoids. A diagnosis of TB needs to be definitively excluded in these patients, ideally by performing a thoracoscopic pleural biopsy.

\section{REFERENCES}

1. Agarwal R. Allergic bronchopulmonary aspergillosis. Chest 2009; 135(3):805-826.

2. Agarwal R, Khan A, Gupta D, Aggarwal AN, Saxena AK, Chakrabarti A. An alternate method of classifying allergic bronchopulmonary aspergillosis based on high-attenuation mucus. PLoS One 2010;5(12): e15346.

3. Agarwal R, Khan A, Garg M, Aggarwal AN, Gupta D. Pictorial essay: allergic bronchopulmonary aspergillosis. Indian J Radiol Imaging 2011;21(4):242-252.

4. Angus RM, Davies ML, Cowan MD, McSharry C, Thomson NC. Computed tomographic scanning of the lung in patients with allergic bronchopulmonary aspergillosis and in asthmatic patients with a positive skin test to Aspergillus fumigatus. Thorax 1994;49(6):586-589.

5. Panchal N, Bhagat R, Pant C, Shah A. Allergic bronchopulmonary aspergillosis: the spectrum of computed tomography appearances. Respir Med 1997;91(4):213-219.

6. Gefter WB, Epstein DM, Miller WT. Allergic bronchopulmonary aspergillosis: less common patterns. Radiology 1981;140(2):307-312.

7. Ricketti AJ, Greenberger PA, Glassroth J. Spontaneous pneumothorax in allergic bronchopulmonary aspergillosis. Arch Intern Med 1984;144(1):151-152.

8. Reich JM. Pneumothorax due to pleural perforation of a pseudocavity containing aspergillomas in a patient with allergic bronchopulmonary aspergillosis. Chest 1992;102(2):652-653.

9. Judson MA, Marshall C, Beale G, Holt JB. Pneumothorax and bronchopleural fistula during treatment of allergic bronchopulmonary aspergillosis. South Med J 1993;86(9):1061-1063.

10. Agarwal R, Aggarwal AN, Gupta D. Efficacy and safety of iodopovidone pleurodesis through tube thoracostomy. Respirology 2006; 11(1):105-108.

11. Li F, Jiang L, Willis-Owen SA, Zhang Y, Gao J. Vitamin D binding protein variants associate with asthma susceptibility in a Chinese Han population. BMC Med Genet 2011;12(1):103.

12. Murphy D, Lane DJ. Pleural effusion in allergic bronchopulmonary aspergillosis: two case reports. Br J Dis Chest 1981;75(1):91-95.

13. Bhagat R, Shah A, Jaggi OP, Khan ZU. Concomitant allergic bronchopulmonary aspergillosis and allergic Aspergillus sinusitis with an operated aspergilloma. J Allergy Clin Immunol 1993;91(5):1094-1096.

14. O'Connor TM, O'Donnell A, Hurley M, Bredin CP. Allergic bronchopulmonary aspergillosis: a rare cause of pleural effusion. Respirology 2001;6(4):361-363.

15. Ogasawara T, Iesato K, Okabe H, Murata K, Kominami S, Tomita K, et al. [A case of pleural effusion associated with allergic bronchopulmonary aspergillosis during a relapse of the disease]. Nihon Kokyuki Gakkai Zasshi 2003;41(12):905-910. Article in Japanese. 


\section{Pleural Effusion in a Patient With Allergic Bronchopulmonary Aspergillosis}

16. Kirschner AN, Kuhlmann E, Kuzniar TJ. Eosinophilic pleural effusion complicating allergic bronchopulmonary aspergillosis. Respiration 2011;82(5):478-481

17. Krenke R, Nasilowski J, Korczynski P, Gorska K, Przybylowski T, Chazan R, et al. Incidence and aetiology of eosinophilic pleural effusion. Eur Respir J 2009;34(5):1111-1117.

18. Min KH, Park SJ, Kim SR, Lee MH, Chung CR, Han HJ, et al. Coexistence of allergic bronchopulmonary aspergillosis and active pulmonary tuberculosis. Am J Respir Crit Care Med 2011;183(1):137-139.

19. Agarwal R, Singh N, Aggarwal AN. An unusual association between Mycobacterium tuberculosis and Aspergillus fumigatus. Monaldi Arch Chest Dis 2008;69(1):32-34
20. Agarwal AK, Bhagat R, Panchal N, Shah A. Allergic bronchopulmonary aspergillosis with aspergilloma mimicking fibrocavitary pulmonary tuberculosis. Asian Pac J Allergy Immunol 1996;14(1): 5-8.

21. Agarwal R, Aggarwal AN, Gupta D, Bal A, Das A. Case report: a rare cause of miliary nodules: allergic bronchopulmonary aspergillosis. Br J Radiol 2009;82(980):e151-e154.

22. Pakdaman MN, Corry DB, Luong A. Fungi linking the pathophysiology of chronic rhinosinusitis with nasal polyps and allergic asthma. Immunological investigations 2011;40(7-8):767-785.

23. Roper WH, Waring JJ. Primary serofibrinous pleural effusion in military personnel. Am Rev Tuberc 1955;71(5):616-634 